\title{
Cooperative Learning in Extension of Participatory Agriculture
}

\author{
Nataliningsih \\ Universitas Bandung Raya \\ Bandung, Indonesia \\ nataliningsih@yahoo.co.id
}

\begin{abstract}
Cooperative learning or the learning of mutual cooperation is one method of learning is done by dividing the responsibility to work together on the task in achieving its objectives. Cooperative learning in formal learning activities is often implemented in study groups or lab, but in non-formal learning activities, especially agricultural extension has not been done, therefore it is necessary to study the implementation of cooperative learning in participatory agricultural extension. The method used is a qualitative approach, by taking purposively, research carried out in Pangalengan, West Java, Indonesia, in potato cultivation farmer groups. Conclusion of The study shows agricultural extension participatory process followed by cooperative learning method produces learning activities that fit their needs and fully followed by all participants of extension. The behaviors transformation after counseling showed 6 $(54.54 \%)$ said it will produce revenue in the processing chips of potato. The improvement of potato chips is $69.74 \%$ in each production. Suggestions submitted to potato farming communities, namely potato chips processing technology to increase revenue, need further development to large-scale production processes with better technology.
\end{abstract}

Keywords-Cooperative learning; non-formal education participation method; change in attitude; increased revenue, agriculture extension

\section{INTRODUCTION}

\section{A. Background}

Agricultural extension is part of non-formal education. Non-formal education are addressed to farmers and their families in managing their farm with the goal of increasing welfare. Non-formal education is applied in agricultural extension has characteristics: a) the location of a flexible (anywhere, farmhouses, fields, according to the will of farmers), b) flexible curriculum (materials according to the needs of farmers, the time is adjusted with the interest and ability of farmers), c) the needs and interests of farmers to find practical ways to overcome the problems faced in managing farming and new things that might be needed by farmers in the development of his farming business), d) presence is not forced [1].

Cooperative learning is a teaching method with a structured system of learning in groups, with a clear division of tasks to the participants involved, and cooperation to achieve the learning objectives. This learning method is also called the learning methods of mutual cooperation, which is implemented in schools so that students interact with each other and eliminate the nature of individualism. In formal education activities, cooperative learning methods are implemented in the lab or in the activities of the task group, working tasks and a clear division of tasks will lead to a sense of shared responsibility for completing the task [2].

The implementation of cooperative learning in agricultural extension activities as contrary to that cooperative learning focuses on teamwork structured to achieve the goal, while agricultural extension as part of the non-formal education is flexible in time, curriculum and attendance is therefore to bridge both of these, implementation agricultural extension done with participatory techniques. Participatory agricultural extension is the agricultural extension activities involving farmers from the needs analysis, setting goals, preparatory counseling, the counseling and evaluation of counseling, so that members of farmers involved will continue to follow the activities of this extension because the extension materials as needed so the process of counseling can be implemented cooperative learning unnoticed by the farmer members [3].

Based on the above background it is necessary to test the implementation of cooperative learning in participatory agricultural extension activities conducted on potato farmer groups in the district of Pangalengan, West Java, Indonesia. The study was conducted by the Agricultural Extension Workers involved in the research sites that have acquired knowledge in the method of participatory agricultural extension.

\section{B. Methods}

1) Research Purposes

- Assessing participatory agricultural extension process with cooperative learning.

- Assessing changes in farmer behavior as a result of the implementation of cooperative learning in participatory agricultural extension.

- Assessing the increase in the income of farmers as a result of the implementation of cooperative learning in participatory agricultural extension. 


\section{2) Usability of Research}

As input for the government in the efforts of agricultural community development as to support the achievement of food security policies.

\section{3) Location of Studies}

The study was conducted in Pangalengan, West Java, Indonesia, on potato cultivation farmer groups were conducted from March to June 2015.

\section{4) Research Methods}

The research method used is a qualitative approach, with three stages of research that is participatory agricultural extension phase, evaluation and evaluation of behavior change farmers increase farmers' income.

\section{LITERATURE REVIEW}

\section{A. Cooperative Learning}

Cooperative are working together to complete the work in order to achieve the goal. There are five main elements in cooperative learning, namely, positive interdependence, individual responsibility, personal interaction, expertise in collaboration and process groups. Thus not all work together in a group can be considered as cooperative learning, the implementation of cooperative learning should include the five basic elements, the division of tasks and responsibilities are clear, as well as the sense of a group to make every citizen of learning involved in cooperative learning will perform the role, duties and responsibility, because no individual success, there is a group success [2]

Learning management using a model of cooperative learning, aims to foster learner in developing and tricks intention to cooperate and interact with other learners. There are three important things in the management of cooperative learning, namely the management of the group, the spirit of implementing cooperative learning atmosphere of the location and arrangement of learning [4].

There are three types of cooperative learning [2], namely: 1) a formal cooperative learning, cooperative learning is applied in classes, 2) informal cooperative learning is done specifically when the demonstration for a few minutes to discussion, 3) cooperative base groups conducted for the learning process so that it takes a long time assistant to monitor the learning process. On participatory agricultural extension activities in this research will be applied is cooperative base group, which farmers' groups serve as an object in the implementation of cooperative learning, and because of this activity takes a long time, then as monitoring conducted by the local Agricultural Extension Workers.

\section{B. Extension of Participatory Agricultural}

The era of globalization is characterized by two things that stand out: 1) the development of information technology and 2) influence of agricultural products from other countries, therefore an agricultural extension must continually improve their knowledge and skills to cope with these developments. Class division's farmer groups to be 4: 1) Class Beginner, 2) Class-up, 3) Medium Class and 4) Class Main consequences of the enactment of the indicators the performance appraisal class farmer groups, so that the heavy duty extension to continue to improve the competence of farmer groups in carrying out his farming business [5].

Participatory agricultural extension is the extension activities involving farmers in every stage of the counseling process, the involvement of farmers began from the needs analysis, in order to obtain extension materials that suit the needs of the farmer groups. In the process of implementation of the farmers involved in the provision of means of pre means of counseling, active in practice, and is involved in the evaluation, so that they know the strengths and the weaknesses that have achieved results which simplify implementation. In this activity will be guided by the Agricultural Extension, so that each stage of agricultural extension participatory, active learning that is resident farmers themselves [6]

Participatory agricultural extension aimed at changing the knowledge, attitudes and skills of farmers. Knowledge is a component of the behavior of farmers who also became a factor in the adoption of innovation, the attitude is one's view of an object that it faces, while the farmer skills is an ability that is manifest or measured in real action [7].

\section{Empowerment of Farmers Group}

The final goal of agricultural development is the realization of the agricultural community welfare through industrial agriculture system, therefore the long-term goal of agricultural development [8], can be specified: 1) The realization of industrial agriculture system that is competitive, 2) consolidation of food security independently, 3) the creation of full employment for the agricultural community, 4) Losing the agricultural communities of poverty and the achievement of farmers' income of US \$4,500 / capita / year. Long-term goals can be achieved through the empowerment of farmers [9].

Community empowerment, can be done with several strategies [10], namely: 1) empowerment of farmers through class group of capabilities, 2) empowerment of farmers through the life cycle, 3) empowerment of farmers through sex, 4) Empowerment through family size, 5) empowerment through levels group, 6) empowerment of farmers through the main commodity (staple). In this research strategy used was to empower farmers through primary commodities (principal) is the group that did the cultivation of potatoes.

The concept refers to efforts to empower farmers cognition and behavior change poor farmers so that they are selfsufficient and productive in meeting the needs of life [11].

\section{RESULTS AND DISCUSSION}

\section{A. The process of participatory extension with cooperative learning}

Cooperative learning is a method of learning to work together to achieve goals, stage in the extension are as follows:

\section{1) Analysis phase of needs}

At this stage, the Agricultural Extension acts as a facilitator, at that time farmer members who come there are 11 people. Facilitators divide tasks ranging from acting as 
chairman of the study group, to prepare a paper problems, recording problems and presenting the results of the analysis of the needs and the remaining 7 as address the problem, each person was given the opportunity to express two problems perceived in the cultivation of potatoes. Results of the needs analysis showed the problems get 2 voters seedlings, pest and disease control get 3 voters, potato processing 7 voters and fertilizer issues by 2 voters. Thus the potato processing problems get highest point is $50 \%$, so that the next extension process is trying demonstration of processing potatoes into French Fries [5]

2) The implementation stage of processing chips with vacuum technique of frying.

During the implementation phase the demonstration of processing chips, the division of labor is done by dividing into two groups, and each group divide tasks, namely parts 1 tool prepare, prepare material 1 , the process drying 1 person, 1 person centrifuge process and packaging 1 . Thus people have a duty and must work closely with the group in order to make French fries processing demonstration, evaluation results conducted through the presentation of the results of the demo, followed by organoleptic tests carried out by all participants with the assessment criteria like, just like and do not like . Results demo shows potato chips produced marketable in terms of organoleptic properties include the appearance, aroma, color, texture and flavor with the average value of love.

\section{3) Evaluation of post-extension behavior with cooperative} learning.

Results of interviews with 11 participants extension showed that $6(54.4 \%)$ said they would try to make potato chips, 3 $(27.2 \%)$ said it wanted to learn in advance on which has been the practice and $2(18.18 \%)$ declare wait after having capital. Participants who want to pioneer the process of potato chips as much as 6 people, they are trying to process household industrial scale, which is planned after the successful processing will seek a port on one of the licenses in order potato chips product can be sold on the market [12].

\section{4) Increasing the value of potato farmers' income}

An impact evaluation conducted after 3 months, which is a review and interviews to farmers who produce potato chips. Observations in the field, participants extension producing potato chips there are three people $(27.2 \%$ of all participants of extension). Every time the production takes $66 \mathrm{~kg}$ of potatoes $(\mathrm{Rp} 7.000,-/ \mathrm{kg})$ and produces $8.66 \mathrm{~kg}$ of potato chips (price $116,000,-/ \mathrm{kg}$ ), the final calculation of income difference is sold in the form of potato chips after being reduced processing cost is $\mathrm{Rp} \mathrm{503.} \mathrm{548,} \mathrm{-} \mathrm{per-once} \mathrm{production.} \mathrm{The} \mathrm{rate} \mathrm{of} \mathrm{profit}$ $503548 / 722000=69.74 \%$ is, therefore potato chip processing business is viable because it increases the income of farmers amounted to $69.74 \%$.

\section{CONCLUSION}

The process of participatory agricultural extension followed up with cooperative learning produces learning activities that fit their needs and fully followed by all participants of extension. Changes in behavior after counseling showed $6(54.54 \%)$ said it will produce potato chips.
3. The increase in revenue in the processing of potatoes was $69.74 \%$ chips in each production.

\section{REFERENCES}

[1] Aker, J. C. (2011). A Review of Information and Communication Technologies for Agricultural Extension in Developing Countries. Dial " A" for Agriculture, JEL Codes

[2] Holobec E.J., J. R. dan J. D. (2007). Cooperative Learning in The Classroom. Virginia: Associ local local local local local ation for Supervision and Curriculum Development, Alexandria, Virginia

[3] Pretty. (1995). Participatory Learning for Sustainable Agriculture. World Development, 23(8), 1247-1263

[4] Lie Anita, 2005. Cooperative Learning. Jakarta : Grasindo.

[5] Wilson, Patricia A. Nordstrom Lowell L.Timothy W. Kelsey, A. N. M. C. W. P. (2000). The Use of Focus Group Interviews to Evaluate Agriculture Educational Materials for Students, Teachers and Consumers. Extension Journal, Inc. ISSN 1077-5315

[6] Rohana P Mahaliyanaarachchi, R. M. A. S. B. (2006). Commercialization of Agriculture and Role of Agricultural Extension. Sabaragamuwa University Journal, 6(1), 13-22

[7] Levies L.R., 2013.Metode Penelitian Perilaku Petani. Indonesia, Yogjakarta : Moya Zam Zam Printika

[8] Sayafa'aat N., Simatupang P., Mardianto S., dan Khudori,2005. Pertanian menjawab Tantangan Ekonomi nasional. Indonesia, Yogjakarta : Lapera Pustaka Utama

[9] Evenson, R. E. (2000). Economic Impacts of Agricultural Research and Extension. New Haven, Yale university: Economic Growth Center P. O. Box 20826927 Hillhouse Avenue New Haven, CT 06520-8269 Phone: 203-432-3626 Fax: 203-432-5591 robert.evenson@yale.edu

[10] Sukino, 2013. Membangun Pertanian dengan Pemberdayaan Masyarakat Petani. Indonesia, Yogjakarta : Pustaka Baru Press.

[11] Rahardjo, M dan S. Rinakit. 1996. "Pemberdayaan Masyarakat Tani" Dalam

[12] Erin M. Hersman Harry N. Boone, J. S. A. G. (2007). Knowledge of Sustainable Agriculture Practices by Extension Agents in Ohio, Pennsylvania, and West Virginia. Journal of Extension, 45(5). Retrieved from nboone@wvu.edu,debby.boone@mail.wvu.edu, sgartin@wvu.edu 